\title{
Post-Harvest Loss of Stored Grain, Its Causes and Reduction Strategies
}

\author{
Marid Tadesse \\ Department of Post-Harvest Management, Jimma University College of Agriculture and Veterinary Medicine, \\ P. O. Box 307, Jimma, Ethiopia
}

\begin{abstract}
Proper postharvest storage of grain is more important than the intensive and extensive farming in securing food for a nation, because losses are not only a waste of food but also represent a similar waste of human effort, farm inputs, livelihoods, investments and scarce recourses such as water. Postharvest losses of stored crops are very common problems in developing countries, like Ethiopia, which has a negative impact on the food security program. This is because poor storage systems make grains vulnerable to attacks from insect and rodent pests, which lead to a considerable amount of losses. In order to help and address the problem of small scale agriculture towards development into a modern production sector, strengthening the postharvest sector or system is essential. It is important to understand postharvest losses in both quality and quantity since it is related to lost income and /or value of commodities produced and hence part of measure and primary concern to bring a food secured nations through modern agricultural production. Postharvest quantity and quality loss of cereal grains in developing countries appears to be initiated mostly at farm-level, so the potential remedies for the problem are needed at the same level. The objectives of this review are, therefore, to assess the available literatures on the postharvest losses of stored grain in an attempt to identify priority areas of the problem; to identify the causes of losses of stored crops in order to avoid the causes for the reduction of losses; and to identify the possible strategies that can reduce losses and maintain quality of the grain during the storage period.
\end{abstract}

Keywords: Factors, losses, postharvest, stored grain.

DOI: $10.7176 /$ FSQM/96-04

Publication date: April $30^{\text {th }} 2020$

\section{INTRODUCTION}

Grains are the main source of nutrition for one-third of the world's poorest population in Sub-Saharan Africa and South-East Asia. Among the grain crops rice, wheat and maize represent about $85 \%$ of total global production (Sofi et al., 2009). In Ethiopia, grain crops are grown annually on approximately 12.5 million hectares of land; of these, 1.5 million hectares is covered by pulses out of which $443,074.68$ hectares is dedicated to Fababean with annual production of about 8,389,438.97 quintals (CSA, 2014). Cereals constituted $87.3 \%$ of the grain production of the country, with $26.8 \%$ contribution from maize, $16.1 \%$ from sorghum and $15.7 \%$ from wheat (CSA, 2015).

Losses resulting from poor post-harvest management of grains are among the key constraints to improving food and nutritional security in Africa, including Ethiopia (Midega et al., 2016). In Ethiopia, grain is often not stored for more than eight months due to poor storage techniques, and inadequate pest management systems (Demissie et al., 2008). Stored grains are damaged by a number of insect pests and rodents that lead to qualitative and quantitative losses during storage. Under farmers "e storage grain losses further aggravated by poor post-harvest handling, inefficient storage facilities and inadequate pest management systems (Demissie et al., 2008; Tefera et al., 2011).

Despite international focus on reduction of postharvest losses, farmers in the developing countries still face significant losses. Postharvest losses can arise from inappropriate storage techniques, deterioration by insect pests and rodents, and abiotic factors (Abass et al., 2014). However, most of the postharvest losses result from damage caused by storage insect pests (Bett and Nguyo, 2007). FAO and World Bank (2010) estimated 20-30\% loss of grains, with an estimated monetary value of more than US\$ 4 billion annually. In Ethiopia, the average grain losses due to storage insect pests estimated to be 10-30\% (Tadesse, 1997). In Ethiopia the major of postharvest pests of cereal grains include the maize weevil (Sitophilus zeamais), the Angoumois grain moth (Sitotroga cereallela) and the lesser grain weevil (Sitophilus oryzae), and Callosobruchus spp. for grain legumes (Demissie et al., 2008; Tefera, 2011). According to Sori and Ayana (2012), S. zeamais can cause heavy infestation on maize and sorghum grain stored under traditional storage facilities and resulted in weight losses up to $41-80 \%$.

Despite the severe losses incurred by insect and rodent pests under poor storage facilities, many farmers in Ethiopia remain using traditional storage structures to store their grains which provide an abundant food source for the pests and aggravate the damage. In most cases, farmers store grain in traditional storage facilities such as gotera and gombisa (Dubale et al., 2012). According to these authors, on-farm storage structures such as gombisa makes maize susceptible to bio-deterioration especially under hot and humid climate. In some instances, farmers are forced to sell their produce immediately after harvest and received low market prices for any surplus grain produce (Kimenju et al., 2009). 
Despite the importance of grains storage for food security, the potential impact of insect pests and rodent infestations on stored grains quality and quantity has not been well investigated. As described by FAO (2014), Kader (2004), Wubeneh and Ehui (2006) and Abebe and Bekele (2006), qualitative and quantitative losses studies are generally sporadic in Africa. Therefore, this review intended: (1) to assess the available literatures on the postharvest losses of stored grain so as to identify priority areas of the problem; (2) to identify the causes of losses of stored grain accordingly in order to show the weight of the problem and its influence on food security and the economy of a country; and (3) to identify the possible strategies that can reduce losses and maintain quality of the stored grain during the storage period.

\section{EXTENT OF POSTHARVEST LOSSES OF STORED GRAIN}

Postharvest loss could occur in crops along the supply chain, starting at the time of harvest till its consumption or end uses (Kidane et al., 2010; FAO and World Bank, 2010).

\subsection{Qualitative losses}

Qualitative losses, such as loss in edibility, nutritional quality, caloric value, and consumer acceptability of the products, are much more difficult to assess than quantitative losses (Buyukbay et al., 2011; Hodges et al., 2014). Post-harvest losses reduce the availability of food crops and income that could be generated by selling these products, thus in terms of quantity is linked to food security (Jayne et al., 2010; Hodges et al., 2011). The qualitative losses are related directly to nutritional and they are more complicated to measure. However, the quantitative losses are of greater importance to measure in developing countries (Humble and Reneby, 2014). Qualitative loss is more frequent based on subjective judgments and is perhaps identified through comparison with locally accepted quality standards. Commodities can be rejected by changes in taste, texture, appearance, loss of nutritional value, and the presence of contaminants. Quality loss can also be due to contamination and foreign matter (insect fragments, rodent hair, excreta, weed seeds, earth, glass, stones, and parts of plants) content (Brown et al., 2013).

\subsection{Quantitative losses}

\subsubsection{Losses of stored grain in the global level}

Estimates of postharvest losses vary in literature, and global figures for losses of $9-40 \%$ are often quoted (Hodges et al., 2014). FAO and World Bank (2010); an approximately 2030\% loss of grains occurred globally, with an estimated monetary value of more than US\$4 billion annually. Recently, Kumar and Kalita (2017) reported approximately 50-60\% losses of cereal grains during storage due to technical inefficiency.

\subsubsection{Losses of stored grain in the sub-Saharan Africa}

Africa remains the continent with greater arable land to feed its growing population and beyond; yet the continent remains the most impoverished in food security (Owusu - Sekyere, 2011). The Sub Saharan Africa (SSA) net food production per annum is within 230 million tons (Gustavsson et al., 2011). Greater portion of this amount is lost due to various factors ranging, for example, poor infrastructure, low levels of technology and low investment in the food production systems, pest, inadequate policies, storage, climate and other factors (Andah, 2000; Gustavsson et al., 2011). Accordingly, the loss of grain due to insect pests are estimated to be within the range of $5-10 \%$ in temperate and 20-35\% in tropical regions (Van Wyk et al., 2009). Hell et al. (2012) reported 10 to $12 \%$ loss of grains stored in traditional storage structures similar to gombisa due to insect pests. Loss of about $18 \%$ was also reported by the same author in other African countries for maize grain stored in sacks for the storage periods of six months.

\subsubsection{Estimation of losses of stored grain in Ethiopia}

In Ethiopia, the average grain losses due to storage pests are about $12 \%$ of the total grain produced; in some case the losses could rise to $50 \%$ (Gabriel and Hundie, 2006). Survey conducted in three major grain producing areas of Ethiopia viz. Hetosa, Ada and Bako indicated that majority of farmers $(93.3 \%)$ are using various traditional grain storage structures that expose their stored grains to be attacked by storage pests and other factors that contribute to deteriorations. Per house hold grain losses of $12 \%$ was estimated from the total grain produced (Gabriel and Hundie, 2006). Eticha and Tadesse (1999) reported an annual maize grain loss in Bako areas in the range between 2 and 30\%. In Jimma Zone, quantitative average maize grain storage loss of 41.0 to $80.0 \%$ and on average $64.5 \%$ of grain damage was estimated in 2004 from fifty traditional farm stores within three to six months of which maize weevil (Sitophilus zeamais) followed by angoumois grain moth (Sitotroga cereallela $(\mathrm{O})$, rice weevil (Sitophilus oryzae) and flour beetle (Tribolium confusum) were identified as major storage pests (Sori and Ayana, 2012).

\subsection{Causes of postharvest losses in stored grain}

Losses in storage are accelerated by late preparation of storage structures, late harvesting, poor storage facilities, storage bags with very low life span and also easily punctured bags by rats (Tadele et al., 2012). High temperature and lack of storage hygiene are the major factors favoring insect and aggravating infestation (Mendesil et al., 2007). 
It is evident that factors, such as high temperature and poor storage hygiene can produce conditions comparatively favorable to insects and so aggravate infestations. High temperature coupled with high relative humidity and high moisture contents of stored produce together with poor storage hygiene favor the development of pests and thereby increase storage pest infestations (Gewinner et al., 1996).

\subsubsection{Insect infestation}

Among the major constraints of grain production and productivity in tropical countries including Ethiopia are the damage caused by insect pests both in the field and storage. Grain is attacked by many insect pests during all stages of growth from seedling to storage (Shiferaw et al., 2011). Insects and other pests are a major threat to grain production and responsible for direct and indirect losses of grain on the farm and storage (Bankole and Mabekoje, 2004). According to Mihale et al. (2009) insects are responsible for $15-100 \%$ and $10-60 \%$ of the pre and postharvest losses of grains in developing countries, respectively. Two major groups of insects are economically important on stored grain: Coleoptera (beetles) and Lepidoptera (moths and butterflies). Crop damage by Lepidoptera is only done by the larvae. In the case of Coleoptera, both larvae and adults often feed on the crop and the two stages are responsible for the damage. Post-harvest insect pests may be primary, that is are those which damage previously undamaged seed such as the genus Sitophilus, while secondary pests are those which cannot damage sound seed but attack seeds which are already damaged either mechanically or by primary pests such as the genus Sitophilus.

The most important insect pests that cause damage to maize and sorghum are stalked borers (in the field) and weevils and moths (in the storage) (Emana and Tsedeke, 1999). The major insect pests of stored grains include maize weevil (Sitophilus zeamais Motsch.), the Angoumois grain moth (Sitotroga cerealella Olivier), the tropical warehouse moth (Ephestia cautella Hubner), the Indian meal moth (Plodia interpunctella Hubner), flour beetle (Tribolium spp.), Cryptolestes spp and Carpophilus spp. (Tadesse, 2003). Maize weevil is a predominant pest widely distributed throughout the warm humid areas of the world. It attacks a wide range of cereals and is well established in tropical countries, including Ethiopia (Akob and Ewete, 2009). In Jima Zone, S. zeamais is the most dominant species and it is widespread, abundant and causes damage and loss of stored grains.

Grain crops including maize and sorghum are often attacked by insect pests in the field prior to harvesting. Adult S. zeamais was observed on all the maize portions of cobs one week after storage, which indicates that the cobs are already infested before harvest. The extent of infestation at the time of harvest can influence the level of damage to the grains in storage (Baidoo et al., 2010). The maize weevil has a host range similar to rice and granary weevil; although it is commonly found on maize, it can also feed on most cereal grains, including sorghum, wheat, barley, rye and rice. Maize weevil prefers the whole grains but has been reported to feed on many processed grain products including pet food and pastas (Mason and McDonough, 2012).

Sitophilus zeamais has been reported to be responsible for $10-20 \%$ of maize losses after three months of storage (Tefera et al., 2011). Thus, due to inefficient storage technologies, millions of tons of maize are lost to insect pests in the world each year. Overall, 20-30\% of Ethiopian stored maize is lost to S. zeamais infestation, while 100\% damage has been found in maize stored for 6 to 8 months in the Bako Region of the country (Demissie et al., 2008). Demissie et al. (2008) found levels of $1159 \%$ weevil infestation in husk-covered maize stored at Bako, Ethiopia, after one month of storage. Weight losses on grains due to the maize weevil vary from region to region depending on the crop variety, storage condition, duration and on pest complex in storage (Sori, 2014). The degree of loss due to insect damage is quite variable and depends on the storage period, storage conditions, storage structures and varieties (Mebeasilassie, 2004). The more the number of adult weevils emerged the more rapid and serious damage (Tefera et al., 2011). It is therefore important that special consideration is given to storage of sorghum. The grain weight losses caused by storage pests on an average were estimated to reach up to $63.85 \%$ within three to six months of storage. However, the weight losses vary from place to place ranging from 35.33 91.67\% (Sori, 2014).

Pulses are invariably infested with beetle and weevil in fields as well as during storage time (Adugna et al., 2006). Callosobruchus chinensis L. is one of the most destructive pests of pulse in storage (Aslam, 2004). The pest not only inflicts qualitative and quantitative losses, but also damages their germinating capacity, and nutritional value which make the grains unfit for human consumption as well (Righi-Assia et al., 2010). Losses as high as 50\% are often encountered in some of the important legumes such as faba bean, field pea, chickpea and lentil from some belligerent storage insect pests like C. chinensis (Damte and Dawd, 2006). Even with only a small amount of actual biological losses, economic losses can reach up to 100\% (Boeke et al., 2004; Somta et al., 2006). Bruchids pose serious post-harvest problem to chickpea and fababean in particular with the extent of damage sometimes exceeding 90\% after three months of storage (Taddesse et al., 2008).

\subsubsection{Rodent infestation}

Rodents are a critical pest issue around the world. Rodents are major pests in cereal grains, causing both qualitative and quantitative damage (Mdangi et al., 2013). Farmers regularly list rodents as one of the foremost significant pests to their crops (Makundi et al., 2005). Numerous analysts moreover respect rodents as the number one group of mammals in terms of the issues they make in farming, cultivation, ranger service, and open wellbeing (Brown 
et al., 1999). In Ethiopia, among 84 recognized rat species, around a dozen of the species are significant rural pests (Bekele et al., 2003). As of late, Gadisa and Hundera (2015) detailed the nearness of four rat pest species, specifically Rattus, Mastomys natalensis, Arvicanthis dembeensis and Lemniscomys barbarus in in Sekoru District (One of the districts in the present study), Southwest Ethiopia.

Typically it is recognized that rats move from grains areas to grain stores in villages (Brown and Khamphoukeo, 2010). Brown et al. (2013) recommend that rat damage to stored rice in upland Lao villages is as high as $11.7 \%$ which is the equivalent of sufficient rice to feed the ordinary Lao smallholder family for one and a half months. They too point out that the presentation of the remaining stored rice to rats decreases its quality. This implies that the farmeres capacity to get higher costs is additionally adversely influenced by post-harvest rat damage. Mdangi et al. (2013) evaluated how much maize was misplaced per month due to rodents from using traditional capacity structures, which are commonly used in Tanzania. They appeared that $40.4 \%$ of stored maize was misplaced due to rodents for a traditional open storage structure while a closed sack secured by wire coinciding driven to no losses or damage, illustrating that there is extraordinary potential for diminishing postharvest misfortunes by relatively simple means .

Preliminary results in central Ethiopia appeared $26.4 \%$ loss of yield in maize (Bekele et al., 2003) which is very high compared to 5 to $15 \%$ loss of rice in Asia (Singleton, 2003). Rodents not as it were cause physical damage and edit loss but too contaminate crop products by physical contaminants, such as hairs, urine and faeces (Hollander et al., 1997). Poisoning and preventing their access to stored commodities can control them. Natural control also applied to stop rodent damages. For the most part, rats transmit diseases (typhus, rabies, and trichomaisis) and crush and damage building structures (Fekadu, 2007). In any case of storage period, grain pest can attack the stored grain and influence the amount and its quality.

\subsection{POSTHARVEST LOSS REDUCTION STRATEGIES IN STORED GRAIN}

\subsubsection{Traditional methods}

Traditional methods include mechanical removal of insects, infested grains or cobs, winnowing, shaking and restacking the grains led to the disturbance of insects and a reduction of their activity. Heating is suitable for small quantities of produce and for areas that have extended periods of hot and dry weather. However, protection does not last long as the technique does not provide the grain with residual protection. The insect pest tends to be driven away from the grain by the heat but not killed (Demissie, 2006). In South western Ethiopia storage hygiene, exposing sorghum grain to sun, treatment of grains with cow urine and admixing with salt are frequently used cultural practices (Mendesil, 2007). Modified atmospheres produced by composting fresh cow dung and fresh chopped sugarcane both wetted at $60 \%$ moisture content caused the highest adult weevil mortality, followed by quick hose fumigant (Ibrahim and Birhanu, 2014).

Maize and other grain crops are often attacked in the field prior to harvesting by storage insect pests (Demissie et al., 2008; Baidoo et al., 2010). Harvesting immediately after physiological maturity is an important aspect of managing maize weevil infestation (Eticha and Tadesse, 1999). Especially maize weevil infestation on cereal crops starts on field before harvesting (Demissie, 2006). Some of the factors influencing pre-harvest infestation in maize include maturity status of the maize grain, husk cover and time of harvest. Both the length and tightness of the husk leaves of maize cob can affect infestation by weevils. Thus, harvesting of matured cobs could reduce weevil infestation before storage (Demissie et al., 2008; Baidoo et al., 2010).

\subsubsection{Hermetic storage}

Air proof (airtight) storage prevents pest from entering and causes the death of insects left in the store due to lack of $\mathrm{O}_{2}$ and excess $\mathrm{CO}_{2}$. Among the different strategies explored the use of modified atmospheres, which includes changing the extent of the ordinary air constituents of the store oxygen, nitrogen and carbon dioxide to form an air deadly to insects, has given especially promising results (Demissie, 2006). Airtight storage is based on the rule of generating oxygen drained, carbon dioxide enhanced interstitial atmosphere caused by the respiration of the living organisms in the biological system of a sealed storage structure (Vachanth et al., 2010). Airtight storage is an alternative to other methods of storage that ensures commodities from insects and molds (Anankware et al., 2012). Oxygen and dampness impermeable bags protect maize and sorghum superior than traditional storage structures and polypropylene sacks. It reduces storage loss from the current $25 \%$ at traditional storage to $2 \%$ in modern storage and promotes ability of farmers to reduce grain loss (Tadele et al., 2012). It is suitable for protecting small quantities of grain materials but it is too expensive for use for food grains storage (Demissie, 2006).

\subsubsection{Temperature}

The use of high temperature over $40^{\circ} \mathrm{C}$ is one of the management techniques to management stored product insect pests. In the regular air treatment, warm death energy for S. zeamais adults is determined at temperatures between 46 and $52^{\circ} \mathrm{C}$. Sistophilus zeamais is more tolerant to high temperatures than S. oryzae and S. silos. For illustration, in an empty storage having $50^{\circ} \mathrm{C}$ temperature the exposure time to attain total progeny diminishment takes over $160 \mathrm{~min}$ for S. zeamais, $130 \mathrm{~min}$ for S. oryzae and $110 \mathrm{~min}$ for S. granarius (Prazic Golic et al., 2015). Keeping up stored maize at temperatures $\leq 15.0^{\circ} \mathrm{C}$ for longer periods suppressed S. zeamais progeny rise viably (Ileleji et 


\section{al., 2007).}

\subsubsection{Use of inert dusts}

Inert materials, such as ashes, sand and other mineral powders and small sized grains in huge amount are a barrier to the insect movement through filling up the free space in grain bulks (Demissie, 2006). A few rural wastes, such as coffee husk, wood ash and saw dust are used in the management of S. zeamais. Maize kernels treated with $15 \%$ $\mathrm{w} / \mathrm{w}$ wood ash, $30 \% \mathrm{w} / \mathrm{w}$ sawdust and 20 and $30 \% \mathrm{w} / \mathrm{w}$ coffee husks are more effective in impending the development of $F_{1}$ offspring rise (Gemu et al., 2013). Ibrahim et al. (2012) observed that diatomaceous soil diminished the generation of offspring by expanding adult mortality, diminishing oviposition, ovicidal and larvicidal activities. Crude diatomaceous soil appeared great potential as grain protectant against adult Callosobruchus subinnotatus invasion and its efficacy increased with increasing doses and exposure period (Singh et al., 2012).

Diatomaceous earth is a soft, silica rock crumbled into a powder and used as an insecticide, due to its abrasive and absorptive properties. The fine powder absorbs oils from insects' exoskeleton, causing them to dehydrate. Some inert materials are toxic to storage insect pests, resulting in mortality. Demissie et al.(2008) reported that silicone caused $100 \%$ mortality of S. zeamais within seven days" exposure period, at the rates of 1 and $2 \%$. The death of insects caused by diatomaceous earth could be attributed to the dehydration provoked by the abrasiveness of the small particles of the inert dust and adsorption of oils in the body of the insect, which breaks the layer of wax on the epicuticle, exacerbating the fatal loss of water (Kavallieratos et al., 2005). Wood ash as inert dusts induces insect mortality by their physical properties; it desiccates the insect cuticle and provokes suffocation in insect (Jean et al., 2015). The grains treated with inert materials, such as ashes and fossil shield can conserve grain viability (Jean et al., 2015). Inert materials, such as wood ash and sand are used for the management of bean beetle on stored chickpea by causing high adult mortality, reduced egg laid, reduced $F_{1}$ progeny emergence, resulted in low grain damage and low grain weight loss without affecting grain germination in stored chickpea grains (Tabu et al., 2012).

\subsubsection{Host plant resistance}

Grain varieties and landraces differ among themselves in their susceptibility to stored grain insect pests. Such differences may be due to the existence of some levels of resistance in local grain varieties, which are attributed to the morphological or biochemical bases of resistance in grain varieties (Mboya, 2011). Mendesil et al. (2007) reported that in West Ethiopia farmers classified sorghum varieties according to their levels of resistance to stored sorghum insect pests. According to Abebe et al. (2009), the extent of damage during storage depends on the number of emerging adults during each generation and the duration of each developmental time. Thus, varieties allowing rapid and high levels of adult insects" emergence will be more seriously damaged. Sorghum varieties, especially local landraces have characteristics of resistance to Sitophilus species (Chuck-Hernández et al., 2013; Goftishu and Belete, 2014). The grain coat thickness and grain hardness served as a barrier to the penetration of the endosperm by S. zeamais and the varieties are proved to be less susceptible to infestation (Zakka et al., 2013).

Resistance in stored sorghum to insect attack is attributed to the presence of toxic alkaloids or amino acids, insect feeding deterrents, pericarp surface texture, enzyme inhibitors, grain hardness, grain temperature and moisture content (Abebe et al., 2009; Goftishu and Belete, 2014). Bamaiyi et al. (2007) also reported that grain hardness is the main resistance parameter for $S$. oryzae in stored sorghum. Higher levels of lysine and tryptophan decreased the rate of reproduction of S. zeamais (Abebe et al., 2009; Goftishu and Belete, 2014). Further, Arnason et al. (2004) also reported that protein content was negatively correlated with the susceptibility of maize cultivars to $S$. zeamais. The weight of adult weevils emerging from susceptible varieties is heavier due to its ability to supply nutrients that can encourage robust physical development of the pest, whereas resistant varieties that did not support much development have lighter emerging adults attributed to lack of required nutrients for optimal development (Zakka et al., 2013).

\subsubsection{Botanical control}

The hazardous nature of synthetic insecticides leads to search for less hazardous and environment-friendly methods such as the use of botanicals in the control of insect pests. The practice of using natural sources against pests for storage of various household items dates back to the very earliest periods of known history (Suleiman and Rugumamu, 2017). This awareness has created a worldwide interest in the development of alternative strategies for discovery of new insecticides (Dayan et al., 2009). Plant parts and plant products have insecticidal, repellent or ant feeding and development inhibiting effects on S. zeamais (Issa et al., 2011). Powders of Allium sativum L., Capsicum frutescens L. and Zingiber officinale Rosc were reported to have caused total (100\%) adult mortality of S. zeamais in sorghum grains 14 days after introduction under laboratory condition (Suleiman, 2014). The spices were also found effective in reducing grain damage of sorghum from $53.30 \%$ in the control to 3.30 to $33.30 \%$ in the botanical treatments, depending on the concentration applied. Subsistent farmers treat grains with plant products and oils, use physical management methods, such as open sun drying and storing in barns, earthen pots, jars and airtight storage structures. These are less cost effective for storage of large quantities of grain. Most of them are nontoxic to consumers and are readily available (Asawalan andHassanali, 2006). 
Poor farmers in many developing countries who could not afford the synthetic pesticide against stored grain insect pests used botanicals as a traditional control. Due to specific novel mode of action plant extracts and essential oils have advantage over synthetic insecticides against the storage insect pests to minimize the cross resistance to specific target molecule (Betancur et al., 2010). These plant extracts and oils have the ability to produce fumigants. These fumigants play important role in eliminating the insect pest of stored grains with rapid degradation, low toxic effect and local availability (Kerdchoechuen et al., 2010).

\subsubsection{Treating with insecticide}

Chemical insecticides are applied to prevent or suppress insect pest infestations. Fumigants, such as phosphine, cyanogens, ethyl formate and sulfuryl fluoride rapidly kill all life stages of stored product insects in storage structures and still one of the most effective methods for the prevention of stored product losses from insect pests (Donahaye, 2000). Ethiopian farmers treat their stored product with chemical insecticides (Mendesil et al., 2007). Survey conducted in South west Ethiopia indicated that farmers used Actellic 2\%, DDT and Malathion 5\% for storage insect pest management. Moreover, those farmers who live near the towns tended more likely to apply chemical insecticides. However, the majority of the farmers never applied synthetic insecticides mainly because of high cost, unavailability and ineffectiveness of chemical insecticides (Mendesil et al., 2007)

\section{CONCLUSION}

The issues reviewed were limited to evidence of measures of magnitudes of losses at different points along the commodity value chain, factors influencing losses and loss management practices. High moisture content, insect infestation and damage during postharvest handling (packaging, storage and transportation) are the major causes of grains postharvest losses. Appropriate packaging materials, proper storage facilities and transportation are required to minimize these losses. Efficient production and utilization of food crops are needed to increase food self-sufficiency and export earnings. Modern food processing techniques and post-harvest technologies are the main tools used to reduce food losses and maintain their quality. Since deterioration of stored grains results from the interactions among the physical, chemical and biological variables existing in the system, it is important to understand the inter-relations and interactions of these variables in order to design an effective control and management of these factors postharvest loss reduction. In order to attain a high nutritional status, improved postharvest management, reduced post-harvest losses, production of value added products, effective and efficient research programs on the post-harvest sector must be strengthened and promoted.

\section{RECOMMENDATION}

(i) Recent information on magnitude of losses, influencing postharvest loss factors and exemplary management practices in the country is still needed specifically covering value chain points agreed by the entire concerned stakeholders on target staple grains. (ii) Promotion of proven grain postharvest loss mitigating technologies at hand need to continue to reach individual and grouped farmers.

(iii) Although the main causes of postharvest losses are known and documented, it is important to further explore peculiar factors that cause postharvest losses at each production level that will require special attention focusing on the same in relation to physical, bio-chemical and socio-economic aspects

\section{REFERENCES}

Abass AB, Ndunguru G, Mamiro P, Alenkhe B, Mlingi N, Bekunda M (2014). Post-harvest food losses in a maizebased farming system of semi-arid savannah area of Tanzania. Journal of sStored Product Research (57):49 -57

Abebe F, Tefera T, Mugo S, Beyene Y, Vidal S (2009). Resistance of maize varieties to the maize weevil, Sitophilus zeamais (Motsch.) (Coleoptera: Curculionidae). African Journal of Biotechnology. 8 (21): 5937 5943.

Abebe HG, Bekele H (2006). Farmers' post-harvest grain management choices under liquidity constraints and impending risks: ilmplications for achieving food security objectives in Ethiopia. In Proceedings of the International Association of Agricultural Economists Conference.

Adugna H, Dangnew G, Biniam Z, Biniam A (2006). On farm storages studies in Eritrea. African Journal of Biotechnology 5(17):1537-1544

Akob CA, Ewete FK (2009). Laboratory evaluation of bioactivity of ethanolic extracts of plants used for protection of stored maize against Sitophilus zeamais Motschulsky in Cameroon. African Journal of Entomology 17(1):90-94

Anankware PJ, Fatunbi AO, Afreh-Nuamah K, Obeng-Ofori D, Ansah, AF (2012). Efficacy of the multiple layer hermetic storage bags for bio- rational management of primary beetle pests of stored maize. Academic Journal of Entomology 5 (1):47-53

Andah, A. (2000), Technological transitions: Technical upgrading of indigenous food technologies in Africa, ECA - Food Security and Sustainable Development Division.Availableat:http://www.un.org/depts/eca/divis/fssd/

Arnason JT, Baum B, Gale J, Lambert JDH, Bergvinson D, Philogene, BJR, Serratos JA, Mihm J, Jewell DC 
(2004). Variation in resistance of Mexican lanraces of maize to maize weevil Sitophilus zeamais, in relation to taxonomic and biochemical parameters. Euphtica. (74 (3): 227-336

Asawalam EF, Hassanali A (2006). Constituents of the essential oil of Vernonia amygdalina as maize weevil protectants. Tropical and Subtropical Agrosystems. 6(2):95-102

Aslam M (2004). Pest status of stored chickpea beetle Callosobruchus chinensis L. on chickpea. Journal of Entomology 1(1):28-33.

Baidoo PK, Mochiah MB, Owusu-Akyaw M (2010). Levels of infestation on three different portions of the maize cob by the weevil Sitophilus zeamais (Motschulsky). Journal of Science and Technology (Ghana). 30 (3):6596

Bamaiyi LJ, Dike MC, Onu I (2007). Relative susceptibility of some sorghum varieties to the rice weevil Sitophilus oryzaeL. (Coleoptera Curculionidae). Journal of Entomology SustainableAgriculture4 (5): 387392.121):169-173.

Bankole SA, Mabekoje OO (2004). Occurrence of aflatoxins and fumonisins in preharvest maize from southwestern Nigeria. Food Additives and Contaminants (21(3):251- 255

Bekele A, Leirs H, Veshagen R (2003). Composition of rodents and damage estimates on maize farms at Ziway, Ethiopia. ACIAR Monograph (96):262-263.

Betancur RJ, Silva AG, Rodríguez JM, Fischer GS, Zapata SM (2010). Insecticidal activity of Peumus boldus mMolina essential oil against Sitophilus zeamais Motschulsky. Journal of Agricultural Research 70 (3):399407.

Bett C, Nguyo R (2007). Post-harvest storage practices and techniques used by farmers in semi-arid Eastern and Central Kenya. IIn 8th African Crop Science Society Conference, El-Minia, Egypt, 27-31 October 2007 (pp: 1023-1227). African Crop Science Societyn: African Crop Science Conference Proceedings 8:1023-1227.

Boeke SJ, Baumgarta IR, Jvan Loona JA, van Huisa A, Dickea M, Kossoub DK (2004). Toxicity and repellence of African plants traditionally used for the protection of stored cowpea against Callosobruchus maculatus. Journal of Stored Product Research (40(4):423-438.

Brown PR, Hung NQ, Hung NM, van Wensveen M (1999). 15. Population Ecology and Management of Rodent Pests in the Mekong River Delta, Vietnam.

Brown PR, Khamphoukeo K (2010). Changes in farmers ${ }^{e e}$ knowledge, attitudes and practices after implementation of ecologically based rodent management in the uplands of Lao PDR. Crop Protection 29(6):577-582.

Brown PR, McWilliam A, Khamphoukeo K (2013). Post-harvest damage to stored grain by rodents in village environments in Laos. International Bio Deterioration and Biodegradation 82:104-109

Buyukbay EO, Uzunoz M, BAL HSG (2011). Post-harvest losses in tomato and fresh bean production in Tokat province of Turkey. Scientific Research and Essays 6(7):1656-1666

Chuck-Hernández C, Serna-Saldívar SO, García-Lara S (2013). Susceptibility of different types of sorghums during storage to Sitophilus zeamais Motschulsky. Journal of Stored Products Research 54: 34-40.

Chuck HC, Sema-Saldivar SO, Garcia-Lara (2013). Susceptibility of different types of sorghums during storage to Sitophilus zeamaisMotschulsky. Journal of Stored Product Research (54):34-40.

CSA (Central Statistical Agency) (2014). Report on Area and Production of Major Crops, Ethiopia: Central Statistical Authority.

CSA (Central Statistical Agency) (2015). Agricultural Sample Survey, 2011/12 (2004 E.C.), Report on Area and Production of Crops, Volume I, Addis Ababa, Central Statistical Agency of the Federal Democratic Republic of Ethiopia.

Damte T, Dawd M (2006). Chickpea, lentil and grass pea insect pest research in Ethiopia: A review. In: Food and forage legumes of Ethiopia: Progress and prospects. Proceedings of a Workshop on Food and Forage Legumes pp. 22-26.

Dayan FE, Cantrell CL, Duke SO (2009). Natural product in crop protection. Bioorganic and Medicinal Chemistry 17:4022-4034.

Demissie G (2006). Field Infestation of maize by Sitophilus zeamais (Mostch.) (Coleoptera: Curculionidae) at Bako and its management on stored maize. An MSc Thesis Presented to the School of Graduate Studies of Haramaya University, Ethiopia.

Demissie G, Tefera T, Tadesse A (2008). Importance of husk covering on field infestation of maize by Sitophilus zeamais Motsch (Coleoptera: Curculionidea) at Bako, Western Ethiopia. African Journal of Biotechnology $7: 20$.

Donahaye EJ (2000). Current status of non-residual control methods against stored product pests. Crop Protection 19(8-10):571-576.

Dubale B, Waktole S, Solomon A, Geremew B, Sethu MR (2012). Influence of agro-ecologies, traditional storage containers and major insect pests on stored maize (Zea mays L.) in selected woredas of Jimma Zone. Asian Journal of Plant Sciences 11(5):226

Emana G, Tsedeke A (1999). Management of maize stem borer using sowing date at Arsi-Negele. Pest Manage. 


\section{J. Ethiopia 3:47-52.}

Eticha F, Tadesse A (1999). Insect pests of farm-stored sorghum in the Bako area. PestManage Journal of Ethiopia 3:53-60.

FAO and World Bank (2010). Food and Agricultural Organization of the United Nations. Reducing post-harvest losses in grain supply chains in Africa: Lessons learned and practical guidelines.

FAO (2014). The State of Food Insecurity in the World 2012: Economic growth is necessary but not sufficient to accelerate reduction of hunger and malnutrition. FAO Rome, Italy

Fekadu L (2007). Fundamentals science and technology of food grain drying, cleaning and storage practices' Training module for center of research on grain quality, processing and technology transfer, Haramaya University, Ethiopia.

Gabriel AH, Hundie B (2006). Farmers' post-harvest grain management choices under liquidity constraints and impending risks: Implications for achieving food security objectives in Ethiopia (No. 1004-201678504).

Gadisa T, Hundera K (2015).Hundera, K. and Gadisa, T. 2015. The reproductive and feeding ecology of rodents in Sekoru district, Southwest Ethiopia. Journal of Ecology and the Natural Environment. 7(6):188-195.

Gemu M, Getu E, Yosuf A, Tadesse T (2013). Management of Sitophilus zeamais Motshulsky (Coleoptera: Ciurculionidae) and Sitotroga cerealella (Olivier) (Lepidoptera: Gelechidae) using locally available agricultural wastes in southern Ethiopia. Journal of Agricultural and Crop Research 1(1):10-16.

Gewinner J, Harnisch R, Mück O (1996). Manual of the prevention of post-harvest grain losses. Manual of the prevention of post-harvest grain losses.

Goftishu M, Belete K (2014). Susceptibility of sorghum varieties to the Sitophilus zeamais Motsch. (Coleoptera: Curculionidae). African Journal of Agricultural Research 9(31):2419-2426.

Gustavsson, J., Cederberg, C., Sonesson, U., van Otterdijk, R., Meybeck, A. (2011), Global Food Losses and Food Waste: Extent Causes and Prevention, Rome, Food and Agriculture Organization (FAO) of the United Nations.

Hell K, Ognakossan K, Tonou AK, Lamboni Y, Adabe KE, Coulibaly O (2012). Maize stored pests control by PICS-bags: technological and economic evaluation. IITA.

Hodges R, Bernard M, Rembold F (2014). APHLIS-Postharvest cereal losses in Sub-Saharan Africa, their estimation, assessment and reduction.

Hodges RJ, Buzby JC, Bennett B (2011). Postharvest losses and waste in developed and less developed countries: opportunities to improve resource use. Journal of Agricultural Science 149(1):37-45.

Hollander A, Run PV, Spithoven J, Heederik D, Doekes G (1997). Exposure of laboratory animal workers to airborne rat and mouse urinary allergens. Clinical and Experimental Allergy 27(6):617-626

Humble S, Reneby A (2014). Post-harvest losses in fruit supply chains - A case study of mango and avocado in Ethiopia. Karin Hakelius, Swedish University of Agricultural Sciences, Department of Economics.

Ibrahim ND, Audu A, Dike MC, Lawal M (2012). Effect of raw diatomaceous earth and plant powders on Callosobruchus subinnotatus(Pic.) infesting stored Bambara groundnut grains. Scientific Journal of Pure and Applied Sciences 1(1):9-16

Ibrahim A, Birhanu T (2014). Studies on organic materials for the production of modified atmosphere for maize weevil control in stored maize. Journal of Entomology and Zoology Studies 2(4):250-253

Ileleji KE, Maier DE, Woloshuk CP (2007). Evaluation of different temperature management strategies for suppression of Sitophilus zeamais (Motschulsky) in stored maize. Journal of Stored Products Research 43:480-488.

Issa US, Afun JVK, Mochiah MB, Owusu AM, Braimah H (2011). Effect of some local botanical materials for the suppression of weevil populations. Journal of Animal and Plant Sciences 11(3):1466-1473

Jayne TS, Mather D, Mghenyi E (2010). Principal Challenges Confronting Smallholder Agriculture in SubSaharan Africa. World Development 38(10):1384-1398.

Jean WG, Nchiwan NE, Dieudonné N, Christopher S, Adler C (2015). Efficacy of diatomaceous earth and wood ash for the control of Sitophilus zeamais in stored maize. Journal of Entomology and Zoology Studies $3(5): 390-397$

Kader AA (2004). Increasing food availability by reducing postharvest losses of fresh produce. Acta Horticulturae 682:2169-2176.

Kavallieratos NG, Athanassiou CG, Pashalidou FG, Andris NS, Tomanovic Z. (2005). Influence of grain type on the insecticidal efficacy of two diatomaceous earth formulation against Rhyzopertha Dominica (F.) (Coleoptera: Bostrychidae). Pest Management Science 61(15):660-666.

Kerdchoechuen O, Laohakunjit N, Singkornar S (2010). Essential oils from six herbal plants for bio control of the S. zeamais. Journal Horticultural Science 45(4):592-598.

Kidane H, Alemu ZG, Kundhlande G .2010. Causes of household food insecurity in Koredegaga peasant association, Oromiya zone, Ethiopia. Agrekon 44(4):543-560.

Kimenju SC, De Groote H, Hellin H (2009). Preliminary Economic Analysis: Cost effectiveness of the use of 
improved storage methods by small scale farmers in east and southern Africa countries.

International Maize and Wheat Improvement Centre (CIMMYT)

Kumar, D., \& Kalita, P. 2017. Reducing postharvest losses during storage of grain crops to strengthen food security in developing countries. Foods, 6(1), 8. http://dx.doi.org/ 10.3390/foods6010008.

Owusu - Sekyere, B.N. (2011), Commercialization of food processing and preservation in Africa: The need for outcome-based policy imperatives to impact job creation, regional and local economic growth and ensuring consumers' safety. A Paper Presented at the Sustainable Agricultural Development and Food Security Summit 2011 on 29 - 31 August 2011, Southern Sun Grayston Hotel, Sandton, Johannesburg, South Africa

Makundi RH, Bekele A, Leirs H, Massawe AW, Rwamugira W, Mulungu LS, (2005). Farmers' perceptions of rodents as crop pests: A farmer participatory study in Tanzania and Ethiopia. Belgian Journal of Zoology 135:153-157.

Mason LJ, McDonough M (2012). Biology, behavior, and ecology of stored grain and legume insects. Stored Product Protection 1:7.

Mboya R (2011).Study of the Effects of Storage Methods on the Quality of Maize and Household Food Security in Rungwe District, Tanzania (Doctoral dissertation, University of KwaZulu-Natal, Pietermaritzburg) 255p.

Mdangi M, Mulungu LS, Massawe AW, Eiseb SJ, Tutjavi V, Kirsten F, Dlamini N (2013). Assessment of rodent damage to stored maize (Zea mays L.) on smallholder farms in Tanzania. International Journal of Pest Management 59(1):55-62.

Mdangi M, Mulungu LS, Massawe AW, Eiseb S, Tutjavi V, Kirsten F, Belmain SR (2013). Assessment of rodent damage to stored maize (Zea mays L.) on smallholder farms in Tanzania. International Journal of Pest Management 59(1):55-62

Mebeasilassie A (2004). Studies on the pest status of bean bruchid and managements of major bruchid species in central rift valleys of Ethiopia (Doctoral dissertation, M. Sc. Thesis, School of Graduate Studies. Addis Ababa University, Ethiopia).

Mendesil E, Abdeta C, Tesfaye A, Shumeta Z, Jifar H (2007). Farmersee perceptions and management practices of insect pests on stored sorghum in southwestern Ethiopia. Crop Protection 26(12):18171825.

Midega CA, Murage AW, Pittchar JO, Khan ZR (2016). Managing storage pests of maize: Farmers' knowledge, perceptions and practices in western Kenya. Crop Protection 90:142-149.

Mihale MJ, Deng AL, Selemani HO, Kamatenesi MM, Kidukuli AW, Ogendo JO (2009). Use of indigenous knowledge in the management of field and storage pests around Lake Victoria basin in Tanzania. African Journal of Environmental Science and Technology 3:49-71

Prazic Golic M, Andric G, Kljajic P (2015). Effects of $50{ }^{\circ} \mathrm{C}$ temperature on Sitophilus granarius (L.), Sitophilus oryzae (L.) and Sitophilus zeamais (Motsch.) Journal of Pesticide Phytomed 26(3):221-227

Righi-Assia AF, Khelil MA, Medjdoub-Bensaad F, Righi K (2010). Efficacy of oils and powders of some medicinal plants in biological control of the pea weevil (Callosobrchus chinensis L.). African Journal of Agricultural Research 5(12):1474-1481.

Shiferaw B, Prasanna BM, Hellin J, Bänziger M (2011). Crops that feed the world past successes and future challenges to the role played by maize in global food security. Food Security 3(3):307-327.

Singh A, Khare A, Singh AP (2012). Use of vegetable oils as bio pesticide in grain protection -a review. Journal of Bio fertilizers and Bio Pesticides 3:1-114.

Singleton G (2003). Impacts of rodents on rice production in Asia. Los Baños, Laguna: IRRI.

Sofi PA, Wani SA, Rather AG, Wani SH (2009). Quality protein maize (QPM): genetic manipulation for the nutritional fortification of maize. Journal of Plant Breeding and Crop Science 1(6):244-253.

Somta P, Talekar NS, Srinives P (2006). Characterization of Callosobruchus chinensis (L.) resistance in Vigna umbellata (Thunb.) Ohwi and Ohashi. Journal of Stored Product Research 42(342):313327.

Sori W (2014). Storage pests of maize and their status in Jimma Zone, Ethiopia. African Journal of Agricultural Research 7(28):4056-4060.

Sori W, Ayana A (2012). Storage pests of maize and their status in Jimma Zone, Ethiopia. African Journal of Agricultural Research 7(28):4056-4060.

Stefanello R, Londero PMG, Muniz MFB, Alves JS, Fischer L (2015). Chemical composition of landrace maize seeds stored under different conditions. International Food Research Journal 22:918-922.

Suleiman M, Rugumamu CP (2017). Management of insect pests of stored sorghum using botanicals in Nigerian traditional stores. Journal of Stored Products and Postharvest Research 8(9):93-102.

Suleiman M (2014). Efficacy of some spices as sorghum grain protectants against Sitophilus zeamais Motschulsky [Coleoptera: Curculionidae]. African Journal of Agricultural Research 9(9):841845.

Tabu D, Selvaraj T, Singh SK, Mulugeta N (2012). Management of Adzuki bean beetle (Callosobruchus chinensis L.) using some botanicals, inert materials and edible oils in stored chickpea. Journal of Agricultural Technology 8(3):881-902.

Tadele T, Abass AB, Adebayo A (2012). Improved postharvest technologies for promoting food storage, 
processing, and household nutrition in Tanzania pp. 1-20.

Tadesse A (1997). Arthropods associated with stored maize and farmers ${ }^{\text {ee }}$ management practices in the Bako area, Western Ethiopia. Pest Management Journal of Ethiopia (34):71-89.

Tadesse, A., Ayalew, A., Getu, E. and Tefera, T. 2008. Review of Research on Post-Harvest Pests. In: Abraham Tadesse (ed.) 2008. Increasing Crop Production through Improved plant protection. Proceedings of 14th Annual conference of plant protection society of Ethiopia (PPSE), 19-22 December 2006. Addis Ababa, Ethiopia. PPSE and EIAR, Addis Ababa, Ethiopia. (1): 475-580.

Taddese, A. 2003. Studies on some non-chemical insect pest management options on farm-stored maize in Ethiopia. $\mathrm{PhD}$ Thesis presented to the School of Graduate Studies of Giessen University, Germany. 246p.

Tefera T, Mugo S, Likhayo P (2011). Effect of insect population density and storage time on grain damage and weight loss in maize due to the maize weevil, Sitophiluszeamais and the larger grain borer, Prostephanus truncates. African Journal of Agricultural Research (6):2249-2254.

Vachanth MC, Subbu RM, Preethi R, Loganathan M (2010). Controlled atmosphere storage technique for safe storage of processed little millet. Academic Journal of Entomology 3(1):12-14.

Van Wyk, B.E., Van Oudtshoorn, B. and Gericke, N. 2009. Medicinal plants of South Africa. Pp: 465

Wubeneh N, Ehui SK (2006). Technical efficiency of smallholder dairy farmers in the central Ethiopian highlands (No. 1004-2016-78590) paper presentation, International Association of Agricultural Economists Conference, Gold Coast, Australia.

Zakka U, Ndowa ES, Odidika CU (2013). Evaluation of the Performance of Different Maize Varieties against Sitophilus zeamais Motsch. (Coleoptera: Curculionidae) Infestation in the Niger Delta Region of Nigeria. Jordan Journal of Biological Sciences 6(2):99- 104.

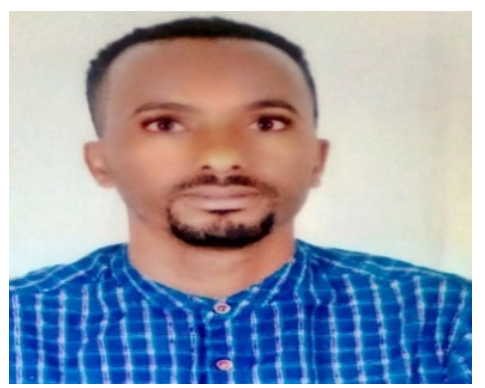

Marid Tadesse is currently the lecturer at Federal TVET institute, Holeta Satellite Campus, Ethiopia. Marid's career began with completing a BSc degree in Post-Harvest Management in 2012 from Jimma University, Ethiopia. He was appointed as assistant researcher at South Agricultural Research Institute, Bonga Research centre working on Food Science and Postharvest Technology. He then joined Jimma University and obtained his MSc in PostHarvest Management in 2018. His research focuses on Assessment of quantitative and qualitative losses of stored grains due to insect infestation in Ethiopia 